\section{Federalism and Youth Employment Policy in Canada}

\section{By Kristin Smith*}

* Kristin Smith is currently a student in the Policy Studies program at Queen's University. This paper was written in December 2001 for a course on Intergovernmental Relations at Dalhousie University.

Résumé

Ce texte discute les effets des relations intergouvernementales au Canada à propos des initiatives d'emploi jeunesse. Ainsi, la juridiction sur les programmes de développement des ressources humaines est une question contestée depuis les années soixante. L'ouvrage décrit premièrement les raisons pour lesquelles Ottawa a décidé de conserver l'autorité sur l'emploi jeunesse en 1996 lors de sa dévolution des programmes d'emploi aux provinces. Il considère, ensuite, les effets de la réponse des provinces, particulièrement la création de la stratégie d'emploi pour les jeunes. Il termine avec une analyse de l'avenir du rôle du gouvernement fédéral dans le domaine de l'emploi jeunesse.

In the arenas of federal-provincial relations, labour market policy has long been a contested issue. Labour market policy encompassed a vast array of changes in its objectives, structure, implementation and administration since the 1960's. The two primary factors in initiating change were an ideological shift to a neo-liberal paradigm from the Keynesian policies of the welfare state, and intergovernmental pressures. Neo-liberal ideologies introduce the notion that supply-side factors together with the dominant demand factors of Keynesian policies can affect the rate of employment. As suggested by Stephen McBride and Peter Stoyko, "the revolution in economic and policy thinking, from Keynesianism to neoliberalism, has been accompanied by policies designed to shrink and/or redefine the role of the state, to liberate market forces from political interference, and to free people from dependency on state-provided social policies." The consequence of this change for labour market policy has been the promotion of a different type of 'active labour market policy,' whereby individuals are more dependent on the market than on the state. The meaning of the term 'active labour market policy' in the current marketoriented paradigm is summarized as "the integration of social policy with labour market policy, including various training and workfare and work experience programs." Neo-liberal ideologies also prompted governments at both levels to create and integrate labour market initiatives with other policy areas, such as education and social welfare policies. This integrated approach creates policy, which transcends departmental boundaries, creating a situation in which the jurisdictional authority of labour market policy is disputed.

The question of jurisdiction is a contested issue since both levels of government claim authority over the areas of labour and training, although each claim is made on the basis of different constitutional powers. The separatist ideologies that took over Quebec politics beginning in the 1960's, involved not only demands for the distinct recognition of Quebec within the Canadian federation, but more specifically, that Ottawa recognize complete provincial jurisdiction of labour market training. Following the 1995 Quebec Referendum, the federal government officially committed to devolving authority over labour market policies to the provinces. This offer to the provinces was incomplete however, since the federal government did not devolve its authority over programs directed towards youth, Aboriginal peoples, and the disabled. This paper will focus on youth employment and the role it plays in intergovernmental relations by analyzing Ottawa's decision to retain authority over youth in the "labour policy offer" made to the provinces in 1996. The view held is that youth employment was treated as an exception to the devolutionary approach to labour market policy perpetuated by the federal government in the mid-1990's. Although the federal government expressed that it would maintain exclusive authority over youth programs, the disputed jurisdictional boundaries of such programs demand the involvement of both levels of government. The federal government announced its massive youth initiative, the Youth Employment Strategy during the same time frame that it was involved in negotiating Labour Market Development Agreements with the provinces. Such an environment created a situation in which the provinces demanded a role in the formation and implementation of youth employment programs.

A brief history of labour market policy in Canada will be outlined as well as the jurisdictional boundaries which make this area a contested issue between the levels of government. The federal government's 1996 decision to devolve authority over labour market policy to the provinces will be discussed, with particular reference to Ottawa's decision to retain 
authority over youth programs. The paper will outline the federal government's reasons for retaining such authority as well as the rationale provided to support such a decision. With the exception of Quebec, there was a coordinated response by all provinces to the incomplete offer made by the federal government. A coordinated and collaborative response from the provinces culminated in the formation and implementation of a National Youth Employment Strategy, in which the federal government is a signatory. The role of the federal government within the area of youth employment has lessened but nevertheless remains paramount through such a coordinated strategy with the provinces. A case study of the Canada-Nova Scotia Youth Protocol will be analyzed as an example of how the collaborative National Youth Employment Strategy has been made a reality. Since the five-year Labour Market Development Agreements between the federal and provincial governments will shortly expire, the final section of this paper will speculate the government's future role in youth employment policies.

\section{Labour Market Policy: A Jurisdictional Juggling Act}

Labour market policy crosses many departments, and more significantly, many jurisdictional boundaries. As Herman Bakvis outlines, the specific areas involved, such as labour market policy, "covers a broad spectrum of activities and instruments, including labour market information, the various means available for allocating labour to different markets, and the training and upgrading of skill sets in light of labour market needs." In terms of federal-provincial relations, training is the most important aspect of labour market policy. As Herman Bakvis suggests, "it is the funding and delivery of training programs that have represented at various times the federal government's major, and at times sole, presence in this field." Training is considered an aspect of education, which is an area of provincial jurisdiction as outlined in Section 93 of the Constitution Act, 1867. The federal government asserts authority over labour market policies by viewing training programs as an economic matter, making the policy area a national priority and federal concern.

While provincial/territorial governments have primary interests

in or exclusive responsibility for education and training, employment programming, social services and health, the federal government has an interest in the overall performance of the national economy, national aspects of the labour market and specific responsibility for the Employment Insurance fund and associated premium rates.
Employment related initiatives introduced by the federal government in the 1960's faced strong opposition from the provinces. The view held by the provinces was that through the use of the federal spending power, Ottawa had taken over an area of distinctly provincial jurisdiction. In order to curb opposition, the provinces were given a role in the delivery of training. Constitutional reform and Quebec's demands for separation and distinct recognition were important factors in the debate over jurisdictional authority of labour market policies and programs. As Bakvis argues, "the ill-fated Charlottetown Accord explicitly recognized Quebec's longstanding demand, namely provincial jurisdiction over labour market training." Other developments which led to changes in labour market policy included the formation of Human Resources Development Canada in 1993, which combined the components of five separate federal departments. Program Review and massive budget cuts initiated by the Liberal government on assuming office in 1993 were also factors in the changes to labour market policy, including youth employment programs.

Jurisdiction over labour market policies was also an important issue for provinces other than Quebec. In the 1995 report, provincial and territorial Labour Market Ministers "pointed to a strong federal role in the provision of income support and a strong provincial role in service delivery." The 1995 Quebec Referendum was quite possibility the strongest factor to entice the federal government to declare labour market policy to fall within provincial jurisdiction. In the months leading up to the referendum, Ottawa was under pressure to recognize Quebec's jurisdictional claims, including provincial jurisdiction of employment and training. As Bakvis notes, "the statement affecting Ottawa's role in labour market development came in the prime minister's speech in Verdun, Quebec, in October of 1995, in which he explicitly recognized that not only Quebec but all provinces had primary jurisdiction over the field of labour market training." The federal offer to devolve authority over labour market policy was made in May 1996. The offer included a federal commitment to withdraw its involvement in employment and training programs and also offered the provinces the opportunity to deliver all components of the new Employment Insurance (EI) Act through funding from the EI fund. The provincial response to the offer was varied. Consequently, three categories of agreements were created from bilateral negotiations: devolution, comanagement and no agreement. Devolution involved a complete acceptance of the federal offer and take over of all active measures set out in the EI Act. The co-management agreements meant that Ottawa would continue to 
administer the five active measures while the provinces gained more authority to determine the disbursement of funds. Upon the writing of this paper, Ontario remains the only province to have not reached an agreement with Ottawa. For the case study that will be presented in the latter part of this paper, it is important to note that Nova Scotia negotiated a comanagement agreement with Ottawa that was based on collaboration between both levels of government.

\section{An Incomplete Offer}

The 1996 offer made by the federal government was incomplete because not all areas of labour market policy were put on the table to be negotiated. Ottawa decided to retain authority over three key areas: youth employment programs, Aboriginal peoples and disability. The federal government's decision to retain authority over youth employment programs was inconsistent with the devolutionary approach to labour market measures as outlined in the Speech from the Throne prior to the offer. The retention of authority over youth employment was also inconsistent with the published report of the 1996 Ministerial Task Force on Youth. The report outlined Ottawa's intentions: "Provincial jurisdiction over education and training will be respected. As with training programs generally, there will be a need for an orderly transition to new arrangements as the Government of Canada withdraws from youth employment programs."

The reasons surrounding the federal government's decision to retain authority over youth programs in the 1996 labour market policy devolution offer to the provinces were primarily political in nature. As to be explained in the latter part of this paper, youth unemployment rates have consistently been reported at crisis levels, thus making youth employment an issue of significant consequence. The Ministerial Task Force on Youth in 1996 described the policy area as a 'national priority.' The federal government decided to retain responsibility to maintain the ability to respond to the crisis. The federal government also asserted its dominant role and responsibility over youth employment programs to gain political credit through visibility. In their recent study of youth employment and intergovernmental relations, Stephen McBride and Peter Stoyko explain: "In contrast to shared-cost programs this [enhancing education opportunities as an antidote to economic insecurity] presents an occasion for high federal visibility and to receive political credit for its youth initiatives." The federal government was able to keep youth programs separate from other aspects of labour market policy since youth employment programs are not funded through the Employment Insurance fund. As Rodney Haddow explains, "youth initiatives are likely to be politically visible and popular, and they can be funded outside of the Employment Insurance fund, which has become a minefield in Ottawa's relations with Quebec and some other provinces." The federal government's decision to retain authority over youth programs was also a response to the results of public opinion polls regarding the crisis situation facing youth. As stated by Edward Greenspon, "public opinion research and feedback from MPs suggests that not only youths but also their parents and grandparents are distressed by the difficulty young people have in breaking into the work force." The most prominent incentive to responding directly and unilaterally to the public's concern regarding the employment situation facing youth was a potential increase in voter support.

The question still remains as to how the federal government can act unilaterally within the realm of youth employment policies and programs. As has been previously outlined, both levels of government lay claim to jurisdictional authority for labour market policies; and youth employment programs are an aspect of this policy area. Thus, the federal government's decision to incompletely devolve labour market policy to the provinces by retaining authority over youth programs is a partial recognition of provincial jurisdictional authority over labour market policy. In defence of its decision to retain authority, the federal government asserted its jurisdiction over youth programs similar to the way it asserted jurisdiction over labour market policy in the 1960's. Ottawa characterized youth employment programs as an economic issue and a national priority that it must oversee unilaterally. McBride and Stoyko argue:

The federal defence of its continued role might be that it is partly motivated by a concern that other federal policies such as high debt levels, cuts in social transfers, uncertainty about the future of the Canada Pension Plan, continued high levels of youth unemployment whether resulting from the overall economic strategy or not, have produced intergenerational inequity. Thus, some kind of corrective action at the federal level is required.

Youth employment policy encompasses a large and diverse set of policies that cut across both departmental and jurisdictional boundaries. Thus, in the area of youth policy, there is much ambiguity surrounding jurisdictional boundaries. As McBride and Stoyko argue, "it is a policy area that often transcends traditional ways of categorizing policy, existing departmental structures, and long-standing jurisdictional boundaries within federations." 
Thus, the federal government created initiatives that integrate the various aspects of youth policy, including education, training and employment programs under one broad heading. Subsequently, Ottawa deemed youth policy to be an economic issue and proclaimed its decision to retain sole authority in this area.

\section{Putting Youth on the Agenda: Responding to the Crisis}

The problem of youth employment, or for a better description, unemployment, became pronounced during the recession of the early 1990's. In 1992, the annual youth unemployment rate reached its highest level since the 1980's recession: $17.8 \%$ compared to the national rate of $11.3 \%$. Table 1 indicates that the youth rate is consistently higher than the national rate.

\section{TABLE 1}

Youth Unemployment Rate (\%) 1978-1998

\begin{tabular}{|l|l|l|}
\hline Year & National Rate & Youth Rate \\
\hline 1978 & 8.4 & 14.4 \\
1979 & 7.5 & 12.8 \\
1980 & 7.5 & 13.1 \\
1981 & 7.6 & 13.1 \\
1982 & 11.0 & 18.6 \\
1983 & 11.9 & 19.7 \\
1984 & 11.3 & 17.7 \\
1985 & 10.5 & 16.3 \\
1986 & 9.6 & 15.0 \\
1987 & 8.9 & 13.5 \\
1988 & 7.8 & 11.9 \\
1989 & 7.5 & 11.2 \\
1990 & 8.1 & 12.7 \\
1991 & 10.4 & 16.2 \\
1992 & 11.3 & 17.8 \\
1993 & 11.2 & 17.7 \\
1994 & 10.4 & 16.5 \\
1995 & 9.5 & 15.6 \\
1996 & 9.7 & 16.1 \\
1997 & 9.2 & 16.7 \\
\hline
\end{tabular}

\begin{tabular}{|c|c|c|}
\hline 1998 & 8.3 & 15.2 \\
\hline
\end{tabular}
201 (Ottawa: Supply and Services Canada, 1998).

The Liberal Party addressed the problem of youth employment within its 1993 election platform. In Creating Opportunity (the 1993 Liberal Party Red Book) it was specifically stated by the Liberals that they would "better prepare for the transition from school to the workplace; provide a constructive outlet for the skills and talents of young Canadians...; [and] enhance the opportunity for job training and improve literacy and numeracy of Canadian workers." The issue of youth employment became a matter of high priority as a result of the consistent crisis unemployment levels and a focus shift within policy discourse of the welfare state. McBride and Stoyko contend that the focus of state support shifted from "prime-age individuals" who are responsible for their economic and social situation to children and youth who are considered more vulnerable to market volatility. They also suggest that "part of the rationale for this is, given fiscal restraint, it is more desirable to target benefits toward those considered most in need but least responsible for their condition." Both a shift of policy focus to youth and high levels of youth unemployment were significant factors placing youth employment programs as a priority on the federal government's agenda.

\section{The Federal Response}

The federal government responded to the crisis of youth employment in various ways to gain the high-profile publicity it felt it could obtain. In March 1996, a Ministerial Task Force on Youth was appointed with the mandate to "consult Canadians to determine how the Government should address the issues facing all youth in making the transition from school to work." The task force report, Take on the Future: Canadian Youth in the World of Work, was published 15 June 1996 and contained a ten-point action plan for dealing with youth issues. An important recommendation of the report, consistent with the government's stance on the issue of youth as perpetuated in the Speech from the Throne in February of that same year, was cooperative action between both levels of government. Similar vocabulary was used in both the Speech from the Throne and the task force report; partnerships and cooperative relationships between both levels of government as well as the non-governmental sector and individuals were referred to as a 'Team Canada' approach. In the Speech from the Throne it was stated that "the Government will challenge the provincial governments and the private sector to enter into a domestic Team Canada partnership to 
create such opportunity for young people." However, when taken as a whole, the report recommended an extension of federal involvement in youth policies and programs. Since the announcement of the federal government's commitment to devolve labour market policy to the provinces had occurred a few weeks prior to the publication of the report, the rhetoric of the Ministerial Task Force on Youth had to be toned down in order to coincide with the current intergovernmental arena.

As a result of the ongoing bilateral negotiations between the provinces and the federal government, Ottawa's Youth Employment Strategy was not announced until the following year. In 1997, Edward Greenspon explained how the environment created by the Labour Market Development Agreements affected the substance of the Youth Employment Strategy.

The \$315-million package [Youth Employment Strategy], promised nearly a year ago, bends over backwards to avoid stepping on provincial toes. One of the reasons for its delay, federal officials say, has been the need to make sure it does not send out cross-signals at a time when Ottawa is negotiating with Quebec and other provinces to get out of employment policies, such as training and wage subsides

The Youth Employment Strategy announced in 1997 focused primarily on internships, which fall within federal jurisdiction. The broad scope of the strategy involves many departments across the government including, Industry, Heritage, Foreign Affairs, Indian and Northern Affairs and the Treasury Board. However, a criticism of the Youth Employment Strategy is its focus on young people with higher levels of education although the unemployment rate of less-educated youth is close to 13 percentage points higher than those with a university education. Such a distorted focus is consistent with the federal government's reasons for refusing to devolve authority over youth programs to the provinces along with other areas of labour market policy. As Greenspon argues, "although the need may be greater for less-educated youth, better educated youth - and their parents tend to be more politically articulate." The federal government's objective to gain political credit and visibility through youth initiatives is evident in both the decision to retain authority and the specific aspects of the Youth Employment Strategy.

The Provincial Response to Incomplete Devolution and Youth: Forming Partnerships
The provincial response to Ottawa's response to retain authority over youth employment programs within the devolution offer made to the provinces in 1996 is varied. Immediately following the government's announcement, provinces that had pressed Ottawa for full devolution were unsatisfied with the federal decision to assert authority over youth employment programs. Quebec claimed that youth employment programs were provincial jurisdiction, and as such must be included in the Labour Market Development Agreements between Ottawa and the provinces. Other provinces agreed to work cooperatively with the federal government to create a National Youth Employment Strategy. As McBride and Stoyko argue, "the Quebec government refused to participate in the development of this kind of pan-Canadian strategy, opting instead to lobby for a youth policy agreement modelled on the Labour Market Development Agreements." The federal government also expressed a willingness to cooperate and collaborate with the provinces in the area of youth employment policies, but was determined to remain a dominant player in the field in order to retain a high level of visibility with the electorate.

At the $38^{\text {th }}$ Annual Premiers' Conference held in New Brunswick in early August 1997, a proposed framework for the development of a national youth employment strategy was introduced. It was proposed by the Provincial-Territorial Ministers that "a national youth employment strategy should be based on a framework which includes the development of shared principles, the identification of areas for priority action and the delineation of clear roles and responsibilities." The proposal was assessed by the Forum of Labour Market Ministers (FLMM), an intergovernmental body of labour market ministers, who established the process by which a national youth employment strategy would be created. The proposal presented by the FLMM outlined the guidelines for a federal-provincial-territorial partnership. The partnership would be "predicated on the assumption that the federal government would agree to set priorities jointly and to coordinate spending on youth employment initiatives with provinces and territories." The five guidelines for the partnership stated the importance of consultation between the levels of government and limiting the federal government's use of the spending power in the areas of youth employment. The five guidelines are as follows:

a) Federal activity in youth employment should occur only after federal-provincial/territorial consultation and provincial/territorial agreement on how federal spending can be effectively applied; 
b) The use of federal spending power in youth employment should not allow the federal government to dictate unilaterally program design and delivery;

c) Areas of joint federal-provincial-territorial responsibility for youth employment should be minimized in those instances in which this would improve the effectiveness of these programs;

d) As responsibilities related to youth employment are clarified and re-aligned, commensurate resources should be made available to the appropriate order of government;

e) The federal government should accept full responsibility for the cost of youth employment programming for Aboriginal people, both on and off the reserve.

Coordination between the levels of government in the area of youth employment was a key part of the proposal, although federalist principles were a dominant aspect of both the original proposal and the final agreement.

In early 1998, A New Federal-Provincial-Territorial Partnership on Youth Employment was completed and initiated bilateral and multilateral agreements between both levels of government to develop joint projects in youth policy. Quebec was not a signatory to this agreement since it continued to lobby that youth employment was a matter of provincial jurisdiction and should be negotiated in a manner consistent with the LMDA. The agreement recognized on the part of the federal government, the importance of provincial involvement in the area of youth employment. However, the role of the federal government remained paramount since high-profile visibility and political credit continued to act as important objectives Ottawa wished to achieve through its role in youth employment.

\section{The Partnership in Action}

The Canada-Nova Scotia Protocol on Youth Employment was negotiated following the completion of the national youth employment strategy. It was a result of the bilateral negotiations between the federal and Nova Scotia governments and is an example of a joint agreement based on the principles of the national youth employment strategy. The protocol follows the collaborative approach of the co-management LMDA reached between Nova Scotia and Ottawa. It is an example of the federal government's commitment to work with the provinces in the areas of youth employment programming. The principles of the Youth Protocol that relate to the new relationship in the area of youth employment are reflective of the intergovernmental relations between Nova Scotia and Ottawa in the area of labour market policy, as well as important democratic principles. The four principles are outlined as follows:

a) Openness and transparency with respect to each Party's activities in youth programs and services;

b) Respect for each Party's roles and responsibilities in youth programming;

c) Coordinated planning, priority setting and implementation so that federal and provincial programs are complementary and build upon each Party's strengths;

d) Reciprocal consultation and information sharing on plans and initiatives.

The Youth Protocol negotiated and agreed upon in Nova Scotia is an example of how the national youth employment strategy had been made into a reality. It shows how the federal and provincial departments can work cooperatively and collaboratively in order to address and solve the crisis facing youth in Nova Scotia.

\section{The Future of Youth Employment Policies}

As has been previously stated, the five-year bilateral LMDA are set to expire in 2002. The argument put forth is that the federal government will continue to treat youth employment programs as an exception from other labour market policies and retain authority in this area. Since the initial devolutionary offer in the area of labour market policy in 1996, in which the federal government decided to retain authority over youth employment, and the enactment of the Youth Employment Strategy, youth employment has remained a federal priority. The 1998 Federal Budget introduced the Canadian Opportunities Strategy, which incorporated youth programming. In the budget announcement, Ottawa admitted that youth unemployment was higher than the national level. Thus, in December 1998, the federal government asserted its commitment to youth employment by renewing the Youth Employment Strategy "with an annual investment of \$155 million." The Speech from the Throne to open the first session of the thirty-seventh Parliament in January 2001 also indicated Ottawa's intentions to maintain a strong role in youth programs. However, the federal government also affirmed its commitment to continue a 'Team Canada' approach to youth 
employment policies by stating that "the Government will continue to help young Canadians contribute to their country, gain employment, and apply their business and creative skills ... The Government of Canada will work with provinces and territories and with non-governmental organizations. More recent federal initiatives in the area of youth employment which demonstrate a strong federal role in this area are the Job Futures and Youth Outlooks programs. Announced in April 2001, Youth Outlooks is a career planning kit with national labour market information to help youth make more informed career and education choices. Both Youth Outlooks and Job Futures demonstrate the government's continued commitment to maintaining a strong and politically visible role within the area of youth programming as well as supporting strong partnerships with the private sector.

The Youth Outlooks kit was funded through the Youth Employment Strategy. Youth Outlooks is a federal initiative designed to facilitate the hiring of young people. It was produced by Human Resources Development Canada (HRDC) to complement Job Futures, which was developed in consultation with 130 business, education and professional organizations, trade unions and sector councils across Canada.

The recent federal youth initiatives are primary examples of the government's primary policy objectives of visibility and political credit.

The federal government continues to maintain a strong role in the framing and implementation of youth employment policies for the similar political reasons associated with the decision to assert its authority in the policy area in the 1996 devolutionary offer. Federal government initiatives instigated since 1996, such as the Youth Employment Strategy, Job Futures and Youth Outlooks, allowed the government to attain political credit and recognition within the electorate for effectively responding to the problems facing youth. In early 1999, Human Resources Development Canada announced that " 143,000 more young people were working in 1998 than 1997 - the greatest increase in the last 20 years," confirming the success of federal government youth initiatives. Political credit and visibility within the public can lead to potential increases in voter support and are thus important considerations made by governments when determining funding for programs. As long as federal youth initiatives continue to be successful and bestow political credit on the federal government, Ottawa will not want to loosen its hold over youth programs. However, in order to avoid jurisdictional conflicts with the provinces, the federal government must continue to tackle the problem of youth employment through a collaborative effort.

\section{Conclusion}

Youth employment was an exception to the devolutionary style of the 1996 federal offer in which the federal government recognized provincial jurisdiction over labour market policy. Ottawa decided to maintain authority over youth programs, an area that many provinces considered a part of labour market policy, in order to gain political credit and high levels of visibility in effectively addressing the crisis problems of youth employment. Political credit and public recognition for the creation of successful youth initiatives have the potential of increasing voter support for the federal government. The massive federal initiative, the Youth Employment Strategy, was announced in the same time period as the bilateral Labour Market Development Agreements were being negotiated inflicting provincial pressure on Ottawa to create a role for the provinces in youth policies. Broad in nature, youth policies transcend both government departments and more importantly jurisdictional boundaries. A combination of the environment set by the LMDA and the nature of youth policies led to the creation of the National Youth Employment Strategy between the federal government and eleven out of the twelve provinces and territories. Quebec was not a signatory to this agreement because the provincial government believes youth employment should be a part of the LMDA. The federal government has benefited from both maintaining a strong, visible role and promoting partnerships with provincial governments in framing and implementing youth employment policies. However, in recent years, Ottawa has begun to shift its policy focus to initiating policies, which center on direct transfers to individuals instead of to the provinces. Examples of policies that transfer funds directly to individuals are the National Child Benefit and Post-Secondary Education. Similar to the government's reasons for retaining authority over youth programs in 1996, such a shift indicates that federal visibility in government programs is an important factor in determining the nature of funding. Ottawa has ensured visibility is an important aspect to be considered when deciding the nature of program funding. For this reason, it is difficult to foresee the federal government devolving authority over youth employment programs to the provinces in the near future. 


\section{References}

Bakvis, Herman. "Checkerboard Federalism? Labour Market Development Policy in Canada," In Canadian Federalism: Performance, Effectiveness and Legitimacy. ed. by Herman Bakvis and Grace Skogstad. Toronto: Oxford University Press, 2002.

"Federalism, New Public Management, and Labour-Market Development," In Canada: The State of the Federation 1996. ed by Patrick C. Fafard and Douglas M. Brown. Kingston: Institute of Intergovernmental Relations, Queen's University, 1996.

and Peter Aucoin. Negotiating Labour Market Development Agreements. Ottawa:

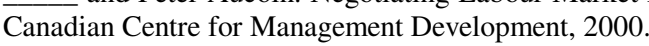

British Columbia. Western Best Practices Report on Youth Employment. 38 ${ }^{\text {th }}$ Annual Premiers' Conference. Ottawa: Canadian Intergovernmental Conference Secretariat, 1997.

Canada. Focus on Youth. Ottawa: Ministry of Supply and Services Canada, 1984.

Speech from the Throne to Open the Second Session of the $35^{\text {th }}$ Parliament of Canada. 27 February 1996. Ottawa: Ministry of Supply and Services Canada, 1996.

Speech from the Throne to Open the First Session of the $37^{\text {th }}$ Parliament of Canada. 30 January 2001. [http://www.sft-ddt.gc.ca/sftddt_e.htm]. 15 October 2001.

Take on the Future: Canadian Youth in the World of Work. Ottawa: Ministry of

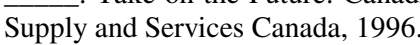

"Canada's Youth Employment Strategy: YES Information and Objectives." [http://www.youth.gc.ca/yesinfo_e.shtml]. 9 November 2001.

Canadian Intergovernmental Conference Secretariat. News Release. "FLMM Endorses New Partnership on Youth / Makes Further Progress on Removing Barriers to InterProvincial Labour Mobility.” 27 March 1998. 1997

News Release. "Joint Communiqué First Ministers' Meeting.” 12 December

Department of Finance Canada. 1998 Federal Budget. "Building Canada for the $21^{\text {st }}$ Century: A Strong Economy and a Secure Society." [http://www.fin.gc.ca/budget98/binbe/binbe.txt]. 26 November 2001.

Greenspon, Edward. "Youth Job Plan Sidesteps Training Ottawa Effort Stresses Work Experience to Avoid Clash with Provincial Services," The Globe and Mail, 6 February 1997, A1.
"Jobs Spotlight on Provinces, Young says Ottawa still Responsible for Economy, but has Shifted Power on Employment," The Globe and Mail, 7 August 1996, A4.

Haddow, Rodney. "How Ottawa Shrivels: Ottawa's Declining Role in Active Labour Market Policy,” In How Ottawa Spends 1998-99. ed. by Leslie A. Pal. Toronto: Oxford University Press, 1998.

Human Resources Development Canada. News Release. "Government of Canada Provides \$800,000 to Youth Skills Competitions," 12 March 1999.

News Release. "Government of Canada Launches Career Planning Tool for Youth," 27 April 2001

News Release. "Youth Employment on the Rise," 5 February 1999.

Kenny, Eoin. "Chrétien Youth,” Canadian Press Newswire, 7 December 1998.

Lavoie, Claude and Ali Béjaoui. Youth Employment Situation in Canada: Explanations and Future Outlook. Hull: Applied Research Branch Strategic Policy, Human Resources Development Canada, 1998.

MacInnis, Karen and Heather Jarmyn. Personal Interview. 16 November 2001.

Marquardt, Richard. Enter at Your Own Risk: Canadian Youth and the Labour Market Toronto: Between the Lines, 1998.

McBride, Stephen and Peter Stoyko. "Youth and the Social Union: Intergovernmenta Relations, Youth Unemployment and School-to-Work Transitions," In Federalism, Democracy and Labour Market Policy in Canada. ed. by Tom McIntosh. Kingston: Institute of Intergovernmental Relations, Queen's University, 2000.

Nova Scotia. Canada-Nova Scotia Protocol on Youth Employment. 10 March 1999.

Nova Scotia. "Investments in Nova Scotians through the Nova Scotia Labour Market Development Agreement.” [http://www.hrdis.ca/lmda]. 17 November, 2001.

Provincial-Territorial Labour Market Ministers. A Provincial/Territorial National Youth Employment Strategy. 29 October1997.

Saskatchewan. Provincial-Territorial Proposed Framework for Development of a Comprehensive Youth Employment Strategy. $38^{\text {th }}$ Annual Premiers' Conference. Ottawa: Canadian Intergovernmental Conference Secretariat, 1997. 